\title{
Prevalence and Risk Factors of HCV Infection among Haemodialysis Patients at Dialysis Centers in Khartoum State - Sudan
}

\author{
Eltagi A. M. Abdalla ${ }^{1 *}$, Kamil M. A. Shaaban ${ }^{2}$, Isam M. Elkhidir ${ }^{3}$ \\ ${ }^{I}$ (Department of Epidemiology, Faculty of Public and Environmental Health, University of \\ Khartoum - Sudan) \\ ${ }_{2}^{2}$ (Department of Community Medicine, Faculty of Medicine University of Khartoum - Sudan) \\ ${ }_{3}^{3}$ (Department of Microbiology, Faculty of Medicine University of Khartoum - Sudan)
}

\begin{abstract}
Hepatitis $C$ virus infection continues to be a major public health problem warranting high priority efforts for control and treatment. Hepatitis $C$ virus infection is a major health problem among dialysis patients in developing countries. This study was conducted to measure the prevalence of HCV and to identify the possible risk factors associated with HCV infection among haemodialysis patients at dialysis centers in Khartoum State, Sudan.

Methods: A cross- sectional facility based study was conducted at ten dialysis centers. A total of 287 subjects were selected. A structured questionnaire was used to collect data on socio-demographic characteristics and risk factors. ELISA was used to test sera for anti-HC. For the analysis, Z-test and Chi-Square test were used. Results: Field workers interviewed ten dialysis centers with a total of 287 study subjects. Sixty out of 287 (20.9\%) was found to be anti-HC reactive. The multivariate analysis indicated as risk factors associated to antiHCV positivity the number of blood transfusion received, duration of dialysis treatment, number of units of treatment, history of surgeries, multiple injections and using share razors. $P$ values $=(0.0001,0.0031,0.0001$, $0.0018,0.0005$ and 0.0002) respectively. The study demonstrated that, duration of dialysis, changing of units of treatment, blood transfusions received, history of surgeries, multiple injections and share razors were considered important risk factors for anti-HC positivity.
\end{abstract}

Keywords: HCV, Haemodialysis patients, risk factor, Khartoum State, Sudan

\section{Introduction}

Hepatitis C virus (HCV) was first characterized by Choo and colleagues in 1989[1]. Approximately, 170 million people worldwide are chronically infected with the hepatitis $\mathrm{C}$ virus (HCV). The prevalence of $\mathrm{HCV}$ infection in patients undergoing dialysis is persistently greater than that in the general population being endemic in haemodialysis (HD) units around the world, predominantly in Mediterranean and developing countries of the Middle and Far East. Nosocomial transmission of HCV infection has been reported to be a considerable route in modern hospital dialysis units, particularly during the outbreaks of infection [1-6].

WHO estimates that $\mathrm{HCV}$ infection has an estimated worldwide prevalence of $>500$ million cases. Low endemicity areas Include North America, Western Europe and Australia, where anti-HCV anti-bodies $<1.5 \%$. Areas with intermediate endemicity Include Mediterranean countries and Asia (Anti-HCV 1-2\%), while the highest endemicity has been detected in Africa, South- Eastern Asia and Latin America (Anti-HCV >2\%) [7].

Haemodialysis patients are at high risk of hepatitis $\mathrm{C}$ infection. Some factors are especially related with these high prevalence rates, such as blood transfusions, length of dialysis time, Kidney transportation, nosocomial contamination, exposure to needle puncture or lesions by cutting instruments, intravenous drugs user, non-isolation of positive patients and others [8-15].

The prevalence of $\mathrm{HCV}$ infection varies greatly among various populations of patients on HD from different geographic regions. The prevalence rates in developed countries such as in Japan (2.5\%), Holland (4\%), the United Kingdom (4\%), Germany (7\%), Belgium (7\%) and Sweden (10\%) are low. However, prevalence is a little bit higher in the USA (14\%), France (15\%), Spain (22\%) and Italy (30\%), in China 41.1\% $[16,17,26]$.

In developing countries the prevalence is higher: in Egypt (52.3 to 82.3\%), in Saudi Arabia (18.9 to $52.5 \%$ ), in Yemen (33.8\%), in Syria (24.4 to 48.9\%), in Tunisia (23\%), in Brazil (18\%), in Turkey (21\%), in India (27.7\%), and in Iran (18.4\%) [3,6,16,18,23,]. In Libya 31.1\%, in Palestine 24.68\%, in Pakistan 23.7\%, in Kosova $43 \%$. [9, $24,25,27]$.

In Sudan located in area with highest endemicity of HCV infection (Anti-HC >2\%)[7]. Several studies were conducted showed prevalence rates of $\mathrm{HCV}$ range from $6.5 \%$ to $23.7 \%$ in haemodialysis patients in different cities through the country [28,29] among HCWs in dialysis units in Khartoum was 1.8\% [30]. Other 
study show the prevalence of HCV among dialysis patients was $8.5 \%$ [31]. The aim of this study was to estimate the prevalence rate of anti-HCV, and to identify possible risk factors for patients in haemodialysis units in Khartoum State, Sudan.

\section{Material And Methods}

Study design: This study was observational, cross-sectional facility based study. It was conducted at ten dialysis centers (units) in Khartoum State.

Study area: Khartoum State is one of the 16 States of Sudan. Khartoum is the political capital and commercial centre of the Sudan with an area of $28165 \mathrm{Km} 2$. It is a located between latitudes 15o- 16o North and longitudes 34o - 31.5o East. Khartoum state can be divided into three geographical areas. The first area: start from Almogran and it lies through between two Nile (Blue and White Nile) until Aljazera state southern, it involve two locality (Khartoum and Jabal Alawlia). The second area: is located in the North side, between Blue Nile and river Nile, it involves North Khartoum locality and East Nile locality. The third area: is located in west White Nile and river Nile and it involve three localities (Omdurman, Umbada and Karari) [8], [9]. There are twenty public dialysis facilities in Khartoum State, this facilities it serve about (2650) haemodialysis patients.

Methods of data collection: A total of 287 subjects were selected using statistical equation $(n=$ $\left.\mathrm{N} / 1+\mathrm{N}(\mathrm{e})^{2}\right)$. Where $\mathbf{n}$ is the sample size, $\mathbf{N}$ is the population size, and $\mathbf{e}$ is the level of precision at Confidence Level is $95 \%$ [16]. A structured questionnaire was used to collect information on socio-demographic characteristics of patients such as, age, gender, marital status, original residence and occupation and past medical history such as blood transfusion and the number of transfusions received, the duration of the haemodialysis treatment, the number of haemodialysis units visited, the use of injectable drugs, surgical operation, sexual habits and tattoos. The nurses responsible for the staff at the studied clinics were interviewed in order to assess whether the prevention measures recommended by the US Center for disease Control and Prevention were being followed.

Laboratory investigation: Under sterilized condition about $(5 \mathrm{ml})$ of venous blood was taken from each study subject through venepuncture using a vacutainer device, the samples was stored upright in an ice box (vaccine carrier) at a temperature of 2-8 degree centigrade and brought to laboratory at the end of the day. Then the sera were separated by centerfugiation at $3000 \mathrm{rpm}$ for 5 mintes, sera were stored at $-20 \mathrm{o} c$ till the testing. All samples were tested for anti-HC by Enzyme-Linked Immunosorbed Assay (ELISA) using commercially available kits (manufactured by Diagnostic Automation, INC. USA).

Data analysis: Data were processed using the Statistical Package for Social Sciences (SPSS) for WINDOW version 19. For the analysis, binomial test (Z-test) for single proportion and some non-parametric tests such as Odds ratio (OR), 95\% confidence interval of CI, and Chi-square test $\left(\mathrm{X}^{2}\right)$ were used, $\mathrm{P}$. value of < 0.05 was considered statistically significant. Informed consent from the selected haemodialysis patients was obtained.

\section{Results}

Two hundred and eighty seven (287) haemodialysis were enrolled in this study70.1\% (204/287) of them were males while $329.9 \%$ (83/287) were females, $45.6 \%$ of participant in age group above 45 years while $32.4 \%$ (93/287) of them in age group $30-45$ and $22 \%$ less than 30 years old. $74.6 \%$ of participant were un married while $25.4 \%$ were married. Regarding to educational level of patients $21.2 \%(61 / 287)$ were illiterate while $12.6 \%$ were graduate (Table1).

Table 2 show the Prevalence of HCV infection according to demographic characteristics of haemodialysis patients. The result show the prevalence HCV infection among haemodialysis patients was $29.9 \%$ (60/287). The results show there is no different according to sex OR 1.28 (95\% CI $0.67-2.45, \mathrm{P}=0.45)$. regarding to age group the findings shows the prevalence of $\mathrm{HCV}$ increase with increasing in age, the results show there was no statistical association between age group and anti-HC positivity $(\mathrm{P}=0.92)$. the results show there is no statistical relationship between marital status, educational level and anti-HC positivity (P.values > $0.05)$.

Table 3 shows the relationship between duration of dialysis, blood transfusion frequency, frequency of dialysis centers and Anti-HC positivity. The results showed there was strongly association between long duration of dialysis and anti-HC positivity $\left(\mathrm{P}=0.0001\right.$ at $\left.\mathrm{X}^{2}=22.888\right)$. The results show the HCV infection increase with increasing in number of blood transfusion, the findings show there was statistical association between blood transfusion and HCV positivity $\left(P=0.0064\right.$ at $\left.X^{2}=12.304\right)$. The result show the patients dialysis in more than three centers more likely to be infected with $\mathrm{HCV}$, the results show there was very strong statistical significant between frequency of dialysis centers and anti-HC positivity $\left(\mathrm{P}=0.00001\right.$ at $\left.\mathrm{X}^{2}=33.372\right)$. able 4 demonstrate the relationship between Anti-HC positivity and some risk factors. The findings show there was significant between history of surgeries and HCV positivity OR 2.52(1.41-4.51, P = 0.0018), also there was strong statistical association between Intravenous drug users (Multiple injections) and positivity of HCV OR 
4.11 (1.86-9.07, $\mathrm{P}=0.0005)$. The results show the patients share the razors were three-and forty seven times more likely to have $\mathrm{HCV}$ infection compared with those not share razors, the results show there statistically significant $3.47(1.80-6.68)$.

The results show there was no relationship between HCV positivity and tattoos, shaving in community barbers and piercing ears $\mathrm{OR} / 95 \% \mathrm{CI}$ and $\mathrm{P}$. values $=1.26(0.58-2.75,1.25(0.70-2.22,1.26(0.58-2.75$ and $0.554,0.435,0.554)$ respectively.

Table (1): Characteristics of haemodialysis patients - Dialysis centers - Khartoum State - Sudan (n=303)

\begin{tabular}{|c|c|c|}
\hline Variable & Frequency & $\%$ \\
\hline Study group & 287 & 100 \\
\hline \multicolumn{3}{|l|}{ Gender } \\
\hline Male & 204 & 70.1 \\
\hline Females & 83 & 29.9 \\
\hline \multicolumn{3}{|l|}{ Age group } \\
\hline$<30$ & 63 & 22 \\
\hline $30-45$ & 93 & 32.4 \\
\hline$>45$ & 131 & 45.6 \\
\hline \multicolumn{3}{|l|}{ Marital status } \\
\hline Married & 73 & 25.4 \\
\hline Unmarried & 214 & 74.6 \\
\hline \multicolumn{3}{|l|}{ Education level } \\
\hline Illiterate & 61 & 21.2 \\
\hline Basic & 97 & 33.8 \\
\hline Secondary & 93 & 32.4 \\
\hline Graduate & 36 & 12.6 \\
\hline
\end{tabular}

Table (2) Prevalence of HCV infection according to demographic characteristics of haemodialysis patients

\begin{tabular}{|c|c|c|c|c|c|c|c|c|c|}
\hline \multirow{3}{*}{ Variables } & \multicolumn{4}{|c|}{ Anti-HC } & \multirow{2}{*}{\multicolumn{2}{|c|}{ Total }} & \multirow[b]{2}{*}{ Odds } & \multirow{2}{*}{$\begin{array}{l}\text { Confidence } \\
\text { interval (CI) }\end{array}$} & \multirow{2}{*}{$\begin{array}{l}P \text { value } \\
\text { val }\end{array}$} \\
\hline & \multicolumn{2}{|c|}{ Negative } & \multicolumn{2}{|c|}{ ositive } & & & & & \\
\hline & No & $\%$ & No & $\%$ & No & $\%$ & \multirow{4}{*}{1.28} & \multirow{4}{*}{$0.67-2.45$} & \multirow{4}{*}{0.45} \\
\hline Gender & & & & & & & & & \\
\hline $\mathrm{Mal}$ & 159 & 55.4 & 45 & 15.7 & 204 & 70.1 & & & \\
\hline Females & 68 & 23.7 & 15 & 5.2 & 83 & 29.9 & & & \\
\hline \multicolumn{10}{|l|}{ Age group } \\
\hline$<30$ & 51 & 17.8 & 12 & 4.2 & 63 & 22 & & & \multirow{3}{*}{$0.92 *$} \\
\hline $30-45$ & 73 & 25.4 & 20 & 7.0 & 93 & 32.4 & & & \\
\hline$>45$ & 103 & 35.9 & 28 & 9.7 & 131 & 45.6 & & & \\
\hline \multicolumn{10}{|c|}{ Marital status } \\
\hline Unmarried & 166 & 57.9 & 48 & 16.7 & 214 & 74.6 & \multirow[b]{2}{*}{1.46} & \multirow[b]{2}{*}{$0.73-2.95$} & \multirow[b]{2}{*}{0.27} \\
\hline Married & 61 & 21.2 & 12 & 4.2 & 73 & 25.4 & & & \\
\hline \multicolumn{10}{|c|}{ Education level } \\
\hline Illiterate & 48 & 16.7 & 13 & 4.5 & 61 & 21.2 & & & \multirow{4}{*}{0.98} \\
\hline Basic & 78 & 27.2 & 19 & 6.6 & 97 & 33.8 & & & \\
\hline Secondary & 73 & 25.4 & 20 & 7.0 & 93 & 32.4 & & & \\
\hline Graduate & 28 & 9.7 & 08 & 2.9 & 36 & 12.6 & & & \\
\hline
\end{tabular}

*P-value considered significant at less than 0.05 levels

Table (3) Relationship between duration of dialysis, blood transfusion frequency, frequency of dialysis centers and Anti-HC positivity

\begin{tabular}{|c|c|c|c|c|c|}
\hline \multirow[t]{3}{*}{ Variable } & \multicolumn{2}{|c|}{ Anti-HC } & \multirow[b]{2}{*}{ Total } & \multirow{3}{*}{ Chi- square } & \multirow{3}{*}{ P. Value } \\
\hline & \multirow{2}{*}{$\begin{array}{r}\text { Negative } \\
\text { No } \\
(\%)\end{array}$} & \multirow{2}{*}{$\frac{\text { Positive }}{\text { No }(\%)}$} & & & \\
\hline & & & $\begin{array}{l}\text { No } \\
(\%)\end{array}$ & & \\
\hline \multicolumn{6}{|c|}{ Duration of dialysis } \\
\hline $\begin{array}{c}<\text { one year } \\
1-5 \\
6-10 \\
>10\end{array}$ & $\begin{array}{c}50(17.5) \\
137(47.8) \\
31(10.8) \\
09(3.1)\end{array}$ & $\begin{array}{c}7(2.4) \\
28(9.7) \\
15(5.2) \\
10(3.5)\end{array}$ & $\begin{array}{c}57(19.9) \\
165(57.5) \\
46(16) \\
19(6.6)\end{array}$ & 22.888 & $0.0001 *$ \\
\hline \multicolumn{6}{|c|}{ Blood transfusion (frequency) } \\
\hline $\begin{array}{c}<5 \text { times } \\
5-10 \\
>10 \text { times } \\
\text { None }\end{array}$ & $\begin{array}{c}64(2.2) \\
55(19.2) \\
44(15.3) \\
64(22.3)\end{array}$ & $\begin{array}{c}8(2.9) \\
18(6.2) \\
23(8.0) \\
11(3.8)\end{array}$ & $\begin{array}{l}72(25.1) \\
73(25.4) \\
67(23.4) \\
75(26.1)\end{array}$ & 13.865 & $0.0031 *$ \\
\hline
\end{tabular}


Prevalence And Risk Factors Of Hcv Infection Among Haemodialysis Patient....

\begin{tabular}{|c|c|c|c|c|c|}
\hline 2 centers & $90(31.3)$ & $10(3.5)$ & $100(34.8)$ & & \multirow{2}{*}{ (3) } \\
3 & $41(14.3)$ & $22(7.7)$ & $63(22.0)$ & 33.372 & \\
4 & $19(6.6)$ & $15(5.2)$ & $34(11.8)$ & & \\
$>=5$ & $15(5.2)$ & $10(3.5)$ & $25(8.7)$ & & \\
centers & $58(20.2)$ & $07(2.5)$ & $65(22.7)$ & & \\
None & & & & & \\
\hline
\end{tabular}

*P-value considered significant at less than 0.05 levels

Table (4) Relationship between Anti-HC positivity and some risk factors

\begin{tabular}{|c|c|c|c|c|c|}
\hline \multirow{3}{*}{ Variable } & \multicolumn{2}{|c|}{ Anti-HC } & \multirow[b]{2}{*}{ Total } & \multirow{3}{*}{$\begin{array}{c}\text { Odds } \\
\text { (Confidence } \\
\text { interval) }(\mathrm{CI})\end{array}$} & \multirow{3}{*}{ P. Value } \\
\hline & Negative & Positive & & & \\
\hline & No $(\%)$ & No $(\%)$ & No $(\%)$ & & \\
\hline \multicolumn{6}{|c|}{ History of surgeries } \\
\hline Yes & $81(28.2)$ & $35(12.2)$ & $116(40.4)$ & \multirow[t]{2}{*}{$2.52(1.41-4.51)$} & \multirow[t]{2}{*}{$0.0018^{*}$} \\
\hline No & $146(50.6)$ & $25(8.7)$ & $171(59.6)$ & & \\
\hline \multicolumn{6}{|c|}{ Multiple injections } \\
\hline Yes & $139(48.4)$ & $52(18.1)$ & 191(66.5) & \multirow[t]{2}{*}{$4.11(1.86-9.07)$} & \multirow[t]{2}{*}{$0.0005^{*}$} \\
\hline No & $88(30.6)$ & $08(2.9)$ & $96(33.5)$ & & \\
\hline \multicolumn{6}{|c|}{ Using share razors } \\
\hline Yes & $64(22.3)$ & $25(8.7)$ & $89(31.0)$ & \multirow[t]{2}{*}{$3.47(1.80-6.68)$} & \multirow[t]{2}{*}{$0.0002 *$} \\
\hline No & $178(62.0)$ & $20(7.0)$ & $198(69.0)$ & & \\
\hline \multicolumn{6}{|l|}{ Tattoos } \\
\hline Yes & $31(10.8)$ & $10(3.5)$ & $41(14.3)$ & \multirow[t]{2}{*}{$1.26(0.58-2.75)$} & \multirow[t]{2}{*}{0.554} \\
\hline No & $196(68.3)$ & $50(17.4)$ & $246(85.7)$ & & \\
\hline \multicolumn{6}{|c|}{ Shaving in community barbers } \\
\hline Yes & $112(39.0)$ & $33(11.5)$ & $145(50.5)$ & \multirow[t]{2}{*}{$1.25(0.70-2.22)$} & \multirow[t]{2}{*}{0.435} \\
\hline No & $115(40.1)$ & $27(9.4)$ & $142(49.5)$ & & \\
\hline \multicolumn{6}{|c|}{ Piercing ears } \\
\hline Yes & $31(10.8)$ & $10(3.5)$ & $41(14.3)$ & \multirow[t]{2}{*}{$1.26(0.58-2.75)$} & \multirow[t]{2}{*}{0.554} \\
\hline No & $196(68.3)$ & $50(17.4)$ & $246(85.7)$ & & \\
\hline
\end{tabular}

$* P$-value considered significant at less than 0.05 levels

\section{Discussion}

Hepatitis C virus (HCV) infection is a major health problem among haemodialysis (HD) patients in developing countries. Hepatitis $\mathrm{C}$ virus infection is a major health problem among haemodialysis patients. In our study we found that, the prevalence of HCV among haemodialysis patients was $29.9 \%$ (95\% CI 0.67-2.45). our result was greater than that found among haemodialysis patients in Sudan (6.5\%, 8.5\% and 23.7\%) $[28,31,29]$. Also our findings greater than that in developed countries, in USA $14 \%$, in France (15\%), United Kingdom (4\%), Germany (7\%) and Spain $(22 \%)$ [16,17, 26]. Our finding was lower than that found haemodialysis patients; in Egypt (52.3 to 82.3\%), in Saudi Arabia (52.5\%), in Yemen (33.8\%), in Syria (24.4 to $48.9 \%)$, in Kosova $43 \%$ and in China $(41.1 \%)$ [9, 24, 25,26,27].

On sex distribution, the results show there is no different according to sex OR 1.28 (95\% CI 0.67 $2.45, \mathrm{P}=0.45$ ). Our finding disagree with that recorded in Palestine among haemodialysis patients, Male patients were found to be more susceptible to HCV than female patients $(p=0.01)$ [22].

The results showed, the positivity of HCV increase with age. In spit that there was no a significant relationship was found between HCV prevalence and age of patients $(P=0.024)$. Our results disagree with that found among haemodialysis patients in Sudan, HCV seropositivity was significantly associated with older age[29]. Also agree with that reported in haemodialysis patients Palestine- Gaza strip [22].

In our study $73.9 \%$ (212/287) of patients received blood transfusion, with 67 (23.4\%) patients having received more than 10 units of blood. This results showed there was significant association between blood transfusion or the number of units received and HCV positivity $(\mathrm{P}=0.0031)$. This result agrees with that found among haemodialysis patients in Sudan, neither blood transfusion, nor the number of blood units received, were significantly associated with hepatitis C seropositivity [29]. Also agree with that recorded among Chinese haemodialysis units, there was an association between the history of blood transfusions and kidney transplantation and the prevalence of HCV infection [15]. Also in line with study carried out in dialysis units in Kosovo, the study showed that duration of dialysis and numbers of transfusions are risk factors for development of HBV and HCV infection [25].

Regarding to the duration of dialysis, the study showed the positivity of HCV increase with increase in duration, the prevalence reach $52.6 \%$ (10/19) among those dialysis more than 10 years. The results showed there was a very strong statistical association between long duration of dialysis and $\mathrm{HCV}$ positivity $(P=0.0001)$. This is in line with what was found by others studies where the risks of HCV infection increase with long duration. In Sudan [29]. In Egypt [2]. In Palestine [27]. In Kosovo [25]. In China [15]. 
The study show that, the patients have history of dialysis in multiple centers, more susceptible to be infected with HCV infection. The result show there was statistical association between anti-HC positivity and dialysis in multiple centers $(P=0.0001)$. This is in line with that was found: In Sudan, HCV seropositivity was significantly associated with dialysis in multiple centers [29]. In Libya, a study showed that HBV or HCV infection was associated with a history of HD in another centre either in Libya or abroad [24].

Our findings revealed that, history of surgeries, multiple injections and using share razors were other risk factors of anti-HC positivity. The results show patients with surgical operation were two-and five times more likely to have HCV infection compared to those who have no history of surgical operation OR 2.52(1.414.51, $\mathrm{P}=0.0018$ ). This result consists with that reported in Sudan, the HCV seropositivity significantly associated with previous surgery [29]. Also agree with that reported among patients in Pakistan, history of surgeries has been present in patients who developed hepatitis C [9]. In relation to multiple injections and HCV infection, our result show patients using multiple injections were four-and twelve times more likely to get HCV infection than those who have not using multiple injections $4.11(1.86-9.07, \mathrm{P}=0.0005)$. This is in line with that was found in Pakistan, history of surgeries has been present in patients who developed hepatitis C [9]. Regarding to using share razors, the study show patients using share razors with others more likely to be infected with HCV three-and forty seven times than those not share razors $3.47(1.80-6.68, \mathrm{P}=0.0002)$.

The study show there was no statistical relationship between HCV positivity and tattoos, shaving in community barbers and piercing ears $P$. values $(0.554,0.435$ and 0.554$)$ respectively.

\section{Conclusion}

The study show the prevalence of HCV among haemodialysis patients was 20.9\%. (Blood transfusions received, duration of dialysis, changing of units of treatment, history of surgeries, multiple injections and share razors) statistically significant predictors factors of anti-HC positivity.

\section{Acknowledgements}

The authors would like to express utmost gratitude to Dr. Wafaa Obied, Director of Training, Information and Researches Management, National Center For kidney Diseases \& Surgery, Ministry of Health, Republic of Sudan, for assistance during the period of study. We are thankful to the staff in the dialysis centers at Khartoum State (Sudan) for their unlimited help. We are especially grateful to the team of data collectors. The authors would like acknowledge to the DAAD for financial support in development to this project.

\section{References}

[1]. Zaller N, Nelson KE, Aladashvili M, Badridze N C D and Tsertsvadze T. Risk factors for Hepatitis C virus infection among blood donors in Georgia. European Journal of Epidemiology 2004; 19: 547-553

[2]. Sabry A, El-Dahshan K, Mahmoud K, El-Husseini A, Sheashaa H and Abo-Zenah H. Effect of hepatitis c virus infection on haematocrit and haemoglobin levels in Egyptian haemodialysis patients. Eur J Gen Med 2007; 4(1):9-15

[3]. Alavian SM, Housseini SMM and Rahnavaradi M. Hepatitis C among Haemodialysis Patients: A Review on Epidemiologic, Diagnostic, and Therapeutic Features. Hepatitis Monthly 2007, 7(3): 153-162

[4]. Souza KP, Luz JA, Teles SA, Carneiro MAS, Oliveira LA, Gomes AS, Dias MA, Gomes SA, Yoshida CFT and Martins RMB. Hepatitis B and C in the Haemodialysis Unit of Tocantins, Brazil: Serological and Molecular Profiles. Mem Inst Oswaldo Cruz, Rio de Janeiro. 2003; 98(5): 599-603

[5]. Saxena AK, Panhotra BR, Sundaram DS, Naguib M, Venkateshappa CK, Uzzaman W, Al Mulhim K and Al-Hasa H. Impact of dedicated space, dialysis equipment, and nursing staff on the transmission of hepatitis $\mathrm{C}$ virus in a hemodialysis unit of the Middle East. Am J Infect Control. 2003; 31:26-33.

[6]. Jasuja S, Gupta AK, Choudhry R, Kher V, Aggarwa DK, Mishra A, Agarwal M, Sarin A, Mishra MK and Raina V. Prevalence and associations of hepatitis C viremia in haemodialysis patients at a tertiary care hospital. Indian Journal of Nephrology. 2009; 19 (2).

[7]. Gogos CA, Fouka KP, Nikiforidis G, Avgeridis K, Sakellaropoulos G, Bassaris H, Maniatis A and Skoutelis A. Prevalence of hepatitis B and C virus infection in the general population and selected groups in South-Western Greece. European Journal of Epidemiology. 2003; 18: 551-557

[8]. Albuquerque ACC, Coelho MR, Lopes EPA, Lemos, MF and Moreira, RC. Prevalence and risk factors of hepatitis C virus infection in haemodialysis patients from one center in Recife, Brazil. Mem Inst Oswaldo Cruz, Rio de Janeiro.2005; 100(5).

[9]. Zarkoon AK, Shah KH, Rehman H, Daud A and Ahmed J. Hepatitis C virus infection in patients on long treatment hemodialysis. Gomal Journal of Medical Sciences January-June. 2008; 6(1).

[10]. Busek SU, Baba EH, Filho HAT, Pimenta L, Salomao A, Oliveira RC and Oliveira GC. Hepatitis C and Hepatitis B Virus Infection in Different Haemodialysis Units in Belo Horizonte, Minas Gerais, Brazil. Mem Inst Oswaldo Cruz, Rio de Janeiro.2002; 97(6): 775-778.

[11]. Catalani C, Biggeri A, Gottard A, Benvenuti M, Frati E and Cecchini C. Prevalence of HCV infection among health care workers in a hospital in central Italy. European Journal of Epidemiology. 2004; 19: 73-77

[12]. Theodore SY and Jamal MM. Epidemiology of Hepatitis C Virus (HCV) Infection. Int. J. Med. Sci. 2006, 3(2):41-46.

[13]. Pantazis KD, Elefsiniotis IS and Brokalaki H. New Data concerning the Epidemiology of Hepatitis B Virus Infection in Greece. Gastroenterology Research and Practice . 2008.

[14]. Center for Disease Control and Prevention (CDC) (2002).Viral hepatitis and injection drugs users. Department of Health and Human Services. Available from: http://www.cdc.gov/idu

[15]. Han L and Shi-xiang W. Hepatitis C viral infection in a Chinese haemodialysis unit. Chinese Medical Journal. 2010; 123(24):35743577 
[16]. Quiroz RJO. Hepatitis C in dialysis units. Director of the Institute of Biomedical Research, School of Health Sciences, University of San Buenaventura. Director of the Department of Gastroenterology, Rev Col Gastroenterol. 2010; 25 (1)

[17]. Santos MAM and Souto FJD. Infection by the hepatitis $C$ virus in chronic renal failure patients undergoing haemodialysis in Mato Grosso state, central Brazil: a cohort study. BMC Public Health 2007; 7(32).

[18]. maied F, Ben Mamou M, Saune-Sandres K, Rostaing L, Slim A, Arrouji Z, Ben Redjeb S and Izopet J. Hepatitis C virus infection among dialysis patients in Tunisia: incidence and molecular evidence for nosocomial transmission. J Med Virol. 2006;78 (2):18591.

[19]. Hussein MM , Mooij JM, Hegazy MS and Bamaga MS. The impact of polymerase chain reaction assays for the detection of hepatitis C virus infection in a haemodialysis unit. Saudi J Kidney Dis Transpl. 2007; 18(1):107-13.

[20]. Bajubair MA, Elrub AA and Bather G. Hepatic Viral Infections in Yemen Between 2000 - 2005. Saudi Med J 2008; 29 (6): $871-$ 874.

[21]. Othman B and Monem F. Prevalence of Antibodies to Hepatitis C Virus among Haemodialysis Patients in Damascus, Syria. Infection. 2001; 29 (5): 262-265.

[22]. El-Ottol AY, Elmanama AA and Ayesh BM. Prevalence and risk factors of hepatitis B and C viruses among haemodialysis patients in Gaza strip, Palestine. Virology Journal. 2010; 7(21).

[23]. Ghanaei FM, Sadeghi A, Mashhour MY and Joukar F. Prevalence of B and C infection in haemodialysis Patients of Rasht (center of Guilan province, North of Iran). Hepatitis Monthly. 2009; 9(1): 45-49.

[24]. Alashek WA, McIntyre CW and Taal MW. Hepatitis B and C infection in haemodialysis patients in Libya: prevalence, incidence and risk factors. BMC Infectious Diseases 2012, 12:265

[25]. Telaku S, Fejza H, Elezi Y and Bicaj T. Hepatitis B and C in dialysis units in Kosova. Virology Journal 2009; 6(72).

[26]. Sun J, Yu R, Zhu B,Wu J, Larsen S and Zhao W. Hepatitis C Infection and Related Factors in Hemodialysis Patients in China: Systematic Review and Meta-Analysis. Informa Healthcare. Renal Failure, 2009; 31:610-620.

[27]. Abumwais JQ and Idris OF. Prevalence of hepatitis C, hepatitis B, and HIV infection among hemodialysis patients in Jenin District (Palestine). Iranian Journal of Virology 2010; 4(2): 38-44

[28]. Abu-Aisha H, Elamin S and Obeid W. Renal Replacement Therapy in Sudan, 2009. Arab Journal of Nephrology and Transplantation. 2010; 3(2):31-6

[29]. El-Amin HH, Osman EM, Mekki MO, Abdelraheem MB, Ismail MO, Yousif MEA, Abass AM, El-haj H S and HK ammar . Hepatitis C virus infection in hemodialysis patients in Sudan: Two centers' report. Saudi J Kidney Dis Transplant 2007;18(1): 101106

[30]. Abdalla EAM and Shappan KMA. Hepatitis C Viral Infection among Health Care Workers at Dialysis Centers in Khartoum State, Sudan. International Journal of Science and Research (IJSR) 2016; 5(10):1258-1261.

[31]. Gasim GI, Hamdan HZ, Hamdan SW AND Adam I. Epidemiology of hepatitis B and hepatitis C virus infections among hemodialysis patients in Khartoum, Sudan. J. Med. Virol. 2011; 84:52-55 